\title{
Section: WORD AND TIME
}

\author{
‘AUTHOR/READER' DICHOTOMY: LINGUISTIC AND COGNITIVE \\ INTENTIONS
}

\author{
VITALIY KONONENKO
}

\begin{abstract}
The purpose of this research is to address the issue of the interaction between the author of a literary text and the reader in the system of linguocognitive intention. The article covers the problems of contextual interpretation of the author's linguistic and artistic strategies, their personality traits, verbal means of creating the image of the author in the addressee's consciousness. In order to get the image of the recipient of the text, one has to make subconscious inferences from the author's comments, statements addressed to the reader, lyrical and epic digressions, etc. The analysis of the texts by modern Ukrainian authors - their linguopoetic paradigm and the intimization of speech technique deployed in order to produce a greater illocutionary effect on the addressee - has made it possible to establish the means and strategies which stimulate communicative process and enhance understanding between the author and the reader. Another problem highlighted in the research is critical perception of the text creator's ego conception and the probability of providing feedback within the 'author/reader' dimension.
\end{abstract}

Keywords: author, reader, addresser, addressee, text, meaning, image, text creation, image creation, unity of language and thought, author's intention, intimization of speech.

The desire of the author of literary texts to bring the reader closer to themselves, to make the reader share their views and emotions, enter their artistic world - even if the author thinks they create for the elite audience - is justified by the very essence of literature, which is produced to be 'consumed'. Modern readers, in their turn, let the ego conception of the author through the prism of their own artistic and aesthetic views; they assess both the artistic value of the work and the author as a thinker, a talented individual. Creating a mental image of the prospective reader, the author believes that both of them belong to the same 'dimension' and counts on the reader's comprehension. The conceptions of the author and the reader overlap; it takes both the author's intention and the reader's opinion to form a common conceptual-notional space, the 'author/reader' dichotomy which includes the systems of images and meanings and is grounded on commonality of thoughts, feelings, and emotions.

Even if the reader accepts the author's views, artistic principles, and language (the unity of language ant thought); even if both of them have similar associations and similar system of images, the reader's inner perception of the text is a complex process, sometimes psychologically unmotivated, sometimes controversial; it involves the reader's own interpretations and new meanings, which results from intellectual, cultural and other differences between the producer and the consumer of the text. According to M. Bakhtin, an utterance is marked by "Addressivity" and "Answerability"; it is always addressed to someone and anticipates, can generate, a response, anticipates an answer. It is formed through a speaker's relation to Otherness (other people, others' words and expressions, and the lived 
cultural world in time and place)' [10]; [1, p. 215]. The reader by nature is not necessarily a critically disposed person; the very fact of their involvement in text comprehension is a proof of their desire to enter the author's spiritual world, it is a sign of their trust in the author as an exponent of whatever is 'wise, kind, eternal'.

The reader perceives the text as a linguistic and aesthetic given, the I-like-it / I-don't-like-it type of comments is not sufficient; the reader sets their own logical and cognitive framework for the analysis of the author's artistic world. Various opinions of the multitude of readers shape, firstly and primarily at the deep semantic level, a general idea about the author and their literary works. The movement from a reader's opinion to condensed propositions is the process of creating the image which is based on the author's character type; this process reveals the ability of the text creator to trigger response from the reader, which may be regarded as a positive manipulative strategy [9].

Consider, for example, how the text (not just the praise of the critics [3]) helps to create in the reader's mind the image of Lina Kostenko, the author of Marusia Churai*. The poet leads us to a paradoxical conclusion: killing Hryts, her character commits crime; at the same time, Marusia is a highly gifted person, and she has already convicted herself; so, she deserves to be acquitted, if not pardoned. This is how the poet presents the inner world of her character: Marusia is silent, yet we know she suffers pangs of conscience and pleads guilty: She was standing as if frozen in motion - / already on the other side of the sun and life. The author even 'tries on' this pain: And I was standing too ... What is the good of crying?.. / What words can I tell them? The reader has to agree with Lina Kostenko unfaithfulness is a great sin. The author sets the highest standards of morality; it makes the reader think and experience emotions, and the author's aim is achieved.

The reader may turn out to be shrewd in their assessment of the author's image; in order to gain the trust of the addressee, the author has to open their heart to the reader, to share their deepest thoughts and doubts, to confess uncertainty, indefinite judgment, unjustified emotions; in other words, not to pretend to be perfect. Only then the reader, who is not perfect either, will have greater trust in the author. For instance, Pokaialni psalmy (Repentant Psalms) by Dmytro Pavlychko show us the image of the person, who not only takes the blame for his ideological mistakes, but also listens to the voice of his conscience. Forgive me, Lord, / My great sins / Committed for love / For my land. / I believed in lies / As a blind man <believes> in his guide, / But the grief for my Fatherland / Opened my eyes. The poet asks his people's forgiveness for his mistakes; the reader can condemn him for his past or may justify him, but the sincerity of the author's voice will not leave the reader indifferent. Pavlychko's repentance shows that he is a passionate, impulsive, sincere person; and the reader understands his pain.

A many-sided image of the author appears to be the result of generalizations, opinions, impressions, discussions amongst readers; it results from the author's texts of different periods and, to some extent, from the author's civic views; the chances of a change in opinion on the author's personality are slim, though time adds new 'colours' to their portrait. For example, Ye. Hutsalo's literary texts open for the reader a wonderful world of the sophisticated lyric writer, a poetic person, who is in love with the nature of his land. The small blue nuts of dew on the three-fingered leaves of cloveras if they are touched with a gentle morning coolness; looking back, you see the dark fringe of footprints hurrying after you; over there, in a tiny valley, which looks like the bottom of a spoon, scattered wisps of fog hang still - like steam over a hot dish. Consider the highly expressive tropes that convey the beauty of the land and author's genuine love for it: nuts of dew, three-fingered leaves, as if touched with a gentle morning coolness, footprints hurrying after you; a tiny valley, which looks like the bottom of a spoon; wisps of fog hang still, like steam over a hot dish. Yet we have to take into account some other typological features of the author's personality, otherwise the image will not be complete. Hutsalo's highly critical journalistc texts distinctly reveal his pain and wrath over the sufferings of his people. The author's image is 'one and undivided', but not one-dimensional; it presents itself in ever more diverse forms.

'I write for myself', 'I write for the drawer (I know it will never be published)', 'I write it to express myself' and suchlike assertions cannon mask the truth - the author wants to get through to the reader

\footnotetext{
All quotations are translated from the original Ukrainian texts.
} 
and to create their own positive image. In the author's imagination, the reader is always a friendly person, a fan, who shares the author's world view and shows (a close) interest in their work. Typically the authors whose target readers are the intellectual elite consciously refuse from widening their circle.

Reading Oksana Zabuzko's popular novel Pol'ovi Doslidžennja z Ukrä̈ns'koho Seksu (Field Researches on Ukrainian Sex), one can easily guess who is the author's target reader - one just has to pay attention to the novel's free style, the 'stream of consciousness' technique, epatage, erotic scenes, echoings, covert quotations, Anglicisms, vulgarisms, etc. In the translation below, Anglicisms and English phrases, which Oksana Zabuzko inserts into her Ukrainian text, are printed in italic, bold style; a covert quotation and a vulgarism, in bold style: ... and she was rushing after the others, from floor to floor, winding her way through the terminal, as in a dream or a horror film, from gate to gate; puffing and panting like a hound, she got to the far-flung corner where they had to board that crop-sprayer aircraft and where her haste shattered itself against a standing-as-firm-as-a-rock, professionally calm clerk behind the counter, "Your plane has just left, ma'am" - and when is the next one? - and the next one is tomorrow at noon - he flashed his teeth, "Have a good night!" - she said "f--- it" and rushed to call Mark... (it is a fragment of a four-pagelong sentence). Zabuzko' reader has to be an educated person, for whom a novel is an intellectual game, who takes aesthetic pleasure in communication with the advanced writer.

Sometimes it seems that the author does not seek consensus with the reader; the system of language and thinking of the modernist writer in particular not always matches self-awareness of the book connoisseur; nevertheless, the reader may recognize the author as an innovator, who coins new metaphors, produces cryptic texts that are comprehensible, but require creative efforts on the part of the reader. For example, an experienced reader, who shares V. Holoborodko's artistic world view, can form associative links between the author's metaphors: In April / in the white sky of cherry milk, / fly golden birds. I The golden birds of roofs. I Having flown for a while, / they, like doves, return to the cottage roof tops. This text may be interpreted as praising the beauty of life, the joys of a spring day, etc. It is evident that Holoborodko's poetic works will filter readers who do not accept his artistic world view, whose reaction will be rejection of the author's manner rather than disagreement with his ego conception. The other, discerning type of reader, the one for whom such poetry is actually meant may find the author's original images quite comprehensible, fitting their picture of the world and the world of emotions [5].

Literary texts enable us to construct the typological paradigm of both the author and the circle of their readers. The authors may be classified as traditionalists and innovators, creators of elite and entertaining literature, 'rulers of the minds' and producers of short-lived things, talented and talentless; likewise, the readers may be interested and indifferent consumers of texts, friendly interlocutors and critically-minded persons, etc. From this array of categories, we may pick the class of discerning readers, book lovers, who cannot do without books, whose quality standards for books are difficult to meet. Trying to win the reader, the author sometimes presents an attractive picture of themselves - a wise person with noble feelings, sincere and truthful; meanwhile, the experienced reader may sense falsehood, insincerity, may see the author's true nature and lose interest in their writings. The author gets no immediate feedback and has to imagine the reader's reaction, which may be equivocal at that; the reader is also a creator, a co-author, who creates the image of the author, which reflects the true nature of the latter.

The writer expects their readers to be educated and creative persons, truthful and empathetic, intelligent or alternatively witty, with a good sense of humour, etc. In accordance with the rules of narratology, the author hides their real face and presents the reader with their various incarnations the agent narrator (i.e. a character), the witness-narrator, the I-narrator and others [8, p. 82-84]; but it does not prevent the reader from recognizing the author, though the reader's perception of the latter may differ from what the text creator wants to look like; this image is variable, it may evoke feelings of sympathy, antipathy, etc. Texts in which the agent narrator is a character that has some common features with the author, are very interesting. It does not matter whether these images coincide or not the reader passes their judgment, disapproves, protests, etc.

Consider the following example: 
I am holding a Mouser pistol in my hand, but my hand is getting weak, and I am about to cry with small tears, like in my childhood, clinging to her warm bosom. I try to cry out, 'Mother! I tell you - come to me! I must kill you' (M. Khvylovyi). Here the antithesis reaches the level of tragedy: my hand is getting weak, I am about to cry, clinging to her warm bosom, on the one hand, and I must kill you, on the other.

The image of the reader, at first glance, is implicit, hidden, difficult to comprehend because the text does not give us any clue to its interpretation (it is not to be found in the text); the author's speech is but their part of an imaginary dialogue with the reader. The reader's comment remains unheard; it is not always that the reader verbalizes it in their mind. Still, it would be wrong to think that we cannot create the reader's image. Readers assess the author's credibility exchanging views and discussing books. After all, there always is an unwritten law of reader assessment - 'interesting', 'captivating', 'you have to read it', 'it is not worth your time' and others - adopted and used in society; the reader's image is not clandestine because it is the reader who is the ultimate authority, the one who creates the image of the author.

The processes of image creation in the 'author/reader' system are not homogeneous in their nature - the author is regarded as the individuality, the text being the platform for expressing their views, their image is presented explicitly; the portrait of the reader is typically the result of generalization, an imaginary thing. But it is a process of associations and assessments, in which both the text creator and the text consumer are involved, in which their image incarnations are brought closer together; at the deep level of text creation, both become reality; it is the highest level of communication. There appears a specific dichotomic unity based on similar comprehension of complex textual meanings, the systems of metaphors and images; this level of comprehension requires common background knowledge; the ego conception of the author becomes, at least to some degree, the reader's position.

Moreover, this dichotomic unity expressed through the formula 'my author - my reader' can explain their common attitude to the characters, closeness of their aesthetic views, ethnic orientations, assessment criteria. For example, in her novel Solodka Darusia (Sweet Darusia), M. Matios appeals to those readers both in Western and Eastern Ukraine who can feel empathy for her characters - the Carpathian villagers.

'About them! About Sweet Darusia and Ivan Tsvychok. Just look at those two poor souls ... Gog save us from such misery ... Would put their heads together and keep silence, two of them, paying no attention to normal people.'

'Who knows, Varvarka dear, how they feel now - happy or unhappy ... who knows ... Maybe there is something in it, just sitting like that - and the rest of the world is nothing to them ...'

Thus the author's idea paves the way to the hearts of her reader.

There is also the problem of objective and subjective modes of text perception. The author's creative thinking determines the subjective nature of narration; still, they want the reader to believe that they are objective, that their fictional reality is depicted quite 'truthfully', and that it all corresponds to the key idea of the text. The reader, who knows that the author is subjective, tries to correlate the text with the reality it is supposed to represent; the subjective/objective perception of the text is a kind of guarantee that the reader comprehends the author's language and way of thinking. According to I. A. Synytsia, the author's subjectivity is represented as explicit; the reader's, as implicit [7, p. 26]; though, it is evident that both the author and the reader reach the level of common subjective/objective perception of the material. A socially concerned, avid, discerning reader can draw parallels between fantasy and reality much better that the author expects; the reader's contribution to the text becomes a factor in their self-assertion, self-realization.

The relations between historical fiction authors and their readers may be ambiguous; the interest in this kind of literature is rising - many Ukrainians want to know the true history of their land, to get rid of ideological stereotypes about the leaders of the past. At the same time, the modern reader still has their doubts: can they trust the author's interpretation of historical events, is the author truthful and unbiased? It is not easy for historical fiction authors to win the trust of their readers, and no surprise 
here - just leaf through the ideologically biased books of the totalitarian past. On the other hand, in historical fiction, fictional figures and events created by the author's imagination are unavoidable.

Consider an excerpt from form the novel Yasa* by Yu. Mushketyk. Sirko, a Cossack Ataman (military leader), orders his people to sabre to death the traitors, who return to captivity; he goes into a monologue, which a real Cossack chieftain was most unlikely to do under the circumstances:

'It makes one sad to see such things,' went on Sirko, 'but it has turned out these people like infidels more than they love their brothers. For them, the land of our enemies is closer than their fathers' land soaked in blood which the Tatars and the Turks have been shedding for years. The faith, which was theirs and their ancestors' from the beginning of times, they sold to the enemy as something at which to mock and laugh. And all this is for the sake of profit, for their own benefit.'

The rhetoric of the speech disagrees with the tragedy of the moment, so the reader may inwardly disagree with the author. V.M. Rusanivskyi comments on the works of Mushketyk the historiographer, '...the events of the past are compared with today's events and there appear "eternal" aphorisms. Evidently, there is a gap between these aphorisms and the author's comprehension of life, but the gap is not big enough to refuse from his usual psychology - to judge life and deeds from allegedly common to all humanity timeless perspective' [6, p. 395]. The author has the right to artistic interpretation of history; the reader has to appreciate the opportunity to immerse themselves in a new story of the bygone days.

The author can get closer to the reader (irrespective of the intended degree of the illocutionary force of their writings); the process presupposes the use of the time-tested literary (linguistic and aesthetic) means and devices, which help to create the atmosphere of trust in what concerns the 'credibility' of the text. For instance, a popular strategy of getting closer to the reader is taking on the role of the narrator, who opens their heart to the reader; it is one of the ways to present the author's ego conception. It is common knowledge that a character, in poetry in particular, cannot be always identified with the author; still, this strategy helps to create preparatory conditions for a sincere conversation with the reader. The strategy provides additional 'preferences' for ' $\mathrm{I}$ ' and 'you' - two people who share the systems of language and thought; and there appears 'we' - the people who can arrive at common conclusions. For example, saying Я стверджуюсь, я утверждаюсь, бо я живу // I assert myself, I am getting stronger because I live, Pavlo Tychyna emphasizes the fact that a creative person lives an active life, works for the common good, etc.

Not infrequently, the author uses ' $\mathrm{I}$ ' to make a character look more 'credible'; this strategy gives the illusion of reading the character's mind, but the monologue-type narration creates the paradox of the author's 'overhearing' the character's thoughts (the reader may vaguely suspect that the author cannot know what a historical figure thought about this or that event); still, the effect of credibility of the text is magnified. For instance, Pavlo Zahrebelnyi's novel Bohdan is written in the form of internal monologue; being aware of the fact that the author could not have read Bohdan Khmelnytsky's mind, the reader, nevertheless, may find the text quite credible and take interest in it. Consider the following excerpt: To what will those who take over from me bring the great cause I have started? Only to decline and complete defeat. There is much bitterness in my words, but they are not unjust. I have plucked them out of obscurity, raised them up, and what do I have for that? Pride, injustice, and revenge even after death ... The closer is my night, the better I see. The words I have started, in my words, I have plucked them out of obscurity, the closer is my night belong to the narrator.

The author becomes more comprehensible, closer to the reader if they use such a popular linguopoetic device as lyrical digressions; its functions is to express - typically, in an emotional and emphatic form - the author's attitude to the characters and events depicted in the text; some characters get the author's approval; others, sympathy; still others, disapproval, even though the described events are distant in terms of time and space. The associative-axiological aspect of the story stands out more clearly; the author's perception may differ from that of the reader, but the very desire to express their

\footnotetext{
* The Ukrainian word яca (yasa) has more than one meaning: signal, sign, rumour, loud sound, roar, thunder, gun salute, salute, tribute, light, radiance.
} 
feelings and, at the same time, to give the reader a gentle 'push' in the right direction helps the author to get closer to the text consumer. This strategy is not popular with modern prose writers; still, it is quite effective and its role in creating emotive backdrop is very important.

For instance, the digressions in Yurii Yanovskyi's prose works are full of lyricism and emotion; their powerful message is 'wrapped' in the metaphorical narrative and meaningful comparisons; such digressions are ingenuous and sincere, and help the author to win the reader's trust. Consider the closing lines of the novel Chotyry shabli (Four Sabres):

Little honeywort grows on sands; white clover, rushes, sedge grow on water; Alpine cinquefoil, scullcaps, hawkweed, meadow-grass, and eryngo, on rocks; in the steppes grow swallowworts, thymus, yarrow, mat-grass; parade themselves goldilocks aster, amaranth, plumeless saw-wort, and autumn hawkbit; serpent root sways in the breeze - as yellow as a dandelion, but tall; and southern globethistle: and people's glory grows from unity and bravery!

This is a rhetorical figure, a complex syntactic unity, whose first part looks too long in its verbosity, too much detailed; the second one seems to be intentionally clipped; but the description of plants has its own deep meaning - it symbolizes the innumerable treasures of the author's native land; the conclusion becomes the conceptualization of the defining categories of heroism - glory, unity, bravery.

The commonality of linguistic and aesthetic views of the addresser and the addressee is another factor that brings their positions closer to each other; in order to achieve the effect, the author employs the strategy of intimization of speech (L. A. Bulakhovskyi's term) [2]. Evidently, the easiest way is to address the reader directly; this strategy activates the illocutionary force of invitation to the author's inner world, where the reader would feel at home; such an invitation implicates comprehension and support on the part of the reader. This type of the general form of address has its own paradigm: alongside the usual form of address - reader - Oksana Zabuzko occasionally uses ladies and gentlemen; this alternative form indicates a closer, exclusive circle of readers. Consider another example. In his famous poem, V. Symonenko repeats the word son:

'Виростеш ти, сину, вирущиш в дорогу, / Виростуть з тобою приспані тривоги

You will grow up, son, and set out on your journey, / And my most deeply hidden worries will grow too'.

Such a form of address has many implications: a young man, a patriot, who is ready to defend his native land ( his people (Батьківщину вибирати не можна // you cannot choose your motherland); after all, the reader who shares the author's views.

The author may use question; at first glance, it looks as if they are self-addressed, but the reader perceives the rhetorical device as something meant for them; if the answer is obvious, the reader accepts it, which means that they think along the same lines. The text presented in the form of questions captures the reader's attention; now the reader is a participant in the process, and it makes the presentation objective because the reader's conclusions coincide with the answers provided by the author. It may seem that rhetorical questions do not help to establish emotionally motivated ties between the author and the reader; but this time-tested device emphasizes the author's desire to win the reader, to make them think over the problem together with the author. A classic example here is the rhetorical questions in Slovo pro ridnu matir (A Song about My Mother):

Who can drain the Dnieper, / Who has the power to spill out the sea, / Who can plough our gold and silver / With the ploughs of lie $<\ldots>$ ?

The sentence is hyperbolic in its exaggerated descriptions, yet the answer is apparent; the author expects the reader to share his admiration for the greatness, might, and beauty of Ukraine.

Various kinds of reticence, elliptical and unfinished sentences, stops in midsentence at an important stage of the story are another strategy to implicate additional ideas, to urge the reader to think over the text and to make inward comment. The reader is a silent 'third party' in the process of text creation; it affects their perception and inconspicuously makes them take the author's side. Consider the following example from Smert kavalera (The Death of the Cavalier) by Hryhir Tiutiunnyk:

'What?' exclaimed Ihorko and jumped to his feet. 'A hero?!'

He darted to the row, hit his head against a board and yelled at the top of his voice, 
'You ... You... You hear ... You?!'

$<\ldots>$

'Hush, silly, hush! Oh, dear ...'

The scene that may seem quite ordinary reveals the personality of the author - the man who speaks the truth, protects poor and mistreated people; in their imagination, the reader completes the verbal picture and takes the brave boy's side; it is not difficult to guess what will be the 'punishment' - it is not for nothing that an old woman, a witness of the conflict, feels sorry for the boy.

The author, who wants the reader to comprehend their 'coded' text, has at their disposal an arsenal of antinomic techniques, which give the reader freedom of interpretation; these are all kinds of allusions, hints meant for the sophisticated and experienced reader, unpredictable situations that challenge them. After all, each author has their own ways to 'enchant' and intrigue the reader, to make them use imagination in order to find the answers if the text is deliberately coded.

Consider an excerpt from H. Kosynka's short story Favst (Faust), which tells us about the fate of an ordinary farmer by the name of Koniushyna, who was accused by the Soviet regime of counterrevolutionary activity. His cell-mates gave him a funny nickname - Faust.

'... everybody liked the new nickname Klientsov had given Koniushyna - 'Faust'. What did it matter that Koniushyna himself did not understand what it meant, that name? Also, it was in the cell that he first heard about the great Goethe.'

The name evokes a number of allusions: it turns out to be the name of an operatic character, not the character in the tragedy by Goethe; then, it is another way to humiliate the poor man; finally, the farmer's fate proves to be much more tragic than the sufferings of Goethe's character. A sacramental question remains unasked: if Koniushyna is Faust, who is Mephistopheles? Presumably, the author meant a generalized image of the 'devil' - the regime that ruins innocent people's lives. It gives the reader a panorama of associations - with the tragedy by Goethe, with the motifs of Mephistopheles's duplicity.

In order to attract attention of an 'ordinary' reader, some authors (for instance, I. Karpa and some other writers who seek to attract young audiences) may use casual, colloquial type of speech - verbal quirks, dirty language, vulgarisms; it refers both to the speech of antagonists and the author's comments. Such attempts at capturing attention of undemanding audience sometimes mask the author's play with the reader, the carnavalization of the process; these endeavours may look artificial, in which case the author will hardly be regarded as an innovator, a ruiner of the classic literary forms; the 'educated' audience is likely to turn away from such experiments.

Another issue which I would like to discuss is the modern reader's attitude to classical Ukrainian literature. How can the phenomenon of interest in the literature of the past centuries be explained? Classical literature depicts events of the old times, the historical past, the people who are unrelated to the problems of modern life. Evidently, there is something in the language and aesthetic principles of the great masters of literature that appeals to the reader. Apart from new content (the reader gets into the world of our ancestors), such works give us a chance to appreciate our cultural heritage, to develop aesthetic taste, linguistic and communicative culture.

For instance, the dramatic story of Mykola Dzheria's life (the same-name novel by Ivan NechuiLevytskyi), provides a path to comprehending the texts of other Ukrainian writers of the late $19^{\text {th }}$-early $20^{\text {th }}$ century - M. Kotsiubynsky, Vasyl Stefanyk, Yurii Yanovskyi, Mykhailo Stelmakh. Consider M. Stelmakh's description of Ukrainian windmills, which clearly shows that the author expects his readers to recognize Nechui-Levytskyi's unhurried, thoughtful manner of writing.

Entering the last but one golden tiredness of the fields, I still feel some overwhelming emotion; and I still cannot calmly look at the last, grey with wind and rain, windmills, at these kind souls of the Ukrainian steppe, which for ages has been filling the pages of clouds and the sky with the dramatic chronicle of the grain-grower's fate.

The continuity of the Ukrainian literary tradition accustoms the reader to thoughtful perception of the text, careful attitude to the word with its numerous nuances of meaning and artistic implicatures. 
The author's image gradually establishes itself in the readers' collective consciousness as objective, socially accepted, complete; at the same time, the reader discovers for themselves new traits of the author's personality and completes the image with their own conclusions, which does not exclude the possibility of critical analysis; having absorbed the author's ideas, the reader reveals their own potential, aesthetic taste. For example, the analysis of the image of Oles' Honchar, the classical Ukrainian writer, will demonstrate a considerable diversity of views and opinions of his literary legacy; nevertheless, Oles' Honchar is fully appreciated as a citizen, a patriot, a great master of the Word. 'Entering the writer's world of language requires a certain level of aesthetic education, knowledge of social and public contexts, in which there develop the national language, its literary style, and within it, the author's idiostyle,' says S. Ya. Yermolenko about Oles' Honchar [4, p. 180]. Thus the author's work influences intellectual and aesthetic development of the reader, their attitudes, feelings, and emotions.

The following lines from Honchar's novel Sobor (The Cathedral) testify to the author's concern for the imperishable treasures of his people: The cathedral has in it something of the elements of nature; it evokes in a person something as great as the steppes, or squadrons of clouds, or black industrial bastions in big factories wrapped in everlasting smokes may evoke ... The silent music of the cathedral, the music of those domes harmoniously raised high into the sky - it really exists, you hear it, though others seems to be deaf to it'. Honchar addresses his words to the readers who can hear the music of the cathedral.

\section{REFERENCES}

[1] Бахтін М. Висловлювання як одиниця мовленнєвого спілкування. В: Зубрицька М. (Ред.) Слово. Знак. Дискурс. Антологія світової літературно-критичної думки ХХ ст. “Дітопис", Аьвів, 1996, 310317.

[Bakhtin M. Vyslovliuvannia yak odynytsia movlennievoho spilkuvannia. In: Zubrytska M. (Ed.) Slovo. Znak. Dyskurs. Antolohiia svitovoi literaturno-krytychnoi dumky XX st. “Litopys", Lviv, 1996, 310-317.]

[2] Булаховський Л.А. Мовні засоби інтимінації в поезії Тараса Шевченка. В: Булаховський А.А. Вибрані твори, том 2. Наук. думка, К., 1977, 273-280.

[Bulakhovskyi L.A. Movni zasoby intyminatsii v poezii Tarasa Shevchenka. In: Bulakhovskyi L.A. Vybrani tvory, tom 2. Nauk. dumka, K., 1977, 273-280.]

[3] Дзюба І.М. Є поети для епох. Аибідь, К., 2011.

[Dziuba I.M. Ye poety dlia epokh. Lybid, K., 2011.]

[4] Ермоленко С.Я. Мовно-естетичні знаки української культури: монографія. Ін-т української мови НАН України, К., 2009.

[Iermolenko S.Ia. Movno-estetychni znaky ukrainskoi kultury: monohrafiia. In-t ukrainskoi movy NAN Ukrainy, K., 2009.]

[5] Кононенко В. Метаморфози сполучуваності в українських модерних поетичних текстах. Studia Ucrainica Varsoviensia, 2, 75-86.

[Kononenko V. Metamorfozy spoluchuvanosti v ukrainskykh modernykh poetychnykh tekstakh. Studia Ucrainica Varsoviensia, 2, 75-86.]

[6] Русанівський В.М. Історія української літературної мови. 2-е вид. “АртЕк”, К., 2002.

[Rusanivskyi V.M. Istoriia ukrainskoi literaturnoi movy. 2-e vyd. “ArtEk", K., 2002.]

[7] Синица И.А. Языковая хичность ученого-гуманитария ХІХ века: монография. Изд. дом Д. Бураго, К., 2006.

[Synytsa Y.A. Yazykovaia lychnost uchenoho-humanytaryia XIX veka: monohrafyia. Yzd. dom D. Buraho, K., 2006.]

[8] Ткачук О.М. Наратологічний словник. Астон, Тернопіль, 2002.

[Tkachuk O.M. Naratolohichnyi slovnyk. Aston, Ternopil, 2002.]

[9] Шкіцька І.Ю. Маніпулятивна тактика позитиву: хінгвістичний аспект: монографія. Вид. дім Д. Бураго, К., 2012. 
[Shkitska I.Iu. Manipuliatyona taktyka pozytyou: linhvistychnyi aspekt: monohrafiia. Vyd. dim D. Buraho, K., 2012.]

[10] Bakhtin M. Main Theories. Dialogism, Polyphony, Heteroglossia, Open Interpretation. A Student's Guide by Martin Irvine. Georgetown University. Available at: http://faculty.georgetown.edu/irvinem/theory /Bakhtin-MainTheory.html.

Address: Vitalii Kononenko, Vasyl Stefanyk Precarpathian National University, 57, Shevchenko Str., IvanoFrankivsk, 76025, Ukraine.

E-mail: kzm.pu.if@yandex.ua.

Received: 12.07.2017; revised: 12.09.2017.

Кононенко Віталій. Дихотомія “автор-читач": лінгвокогнітивні інтенції. Журнал Прикарпатського університету імені Василя Стефаника, 4 (2) (2017), 45-53.

У статті розглянуто проблему взаємодії автора художнього тексту й читача в системі лінгвокогнітивної інтенції. Висвітлено шляхи текстової інтерпретації притаманних письменникові мовотвірних уподобань, рис особистісної вдачі, словесної автохарактеристики в свідомості адресата. Постать одержувача текстів постає в світлі імпліцитного підсвідомого домислювання, посиденого авторським коментуванням, зверненнями до читача, діроепічними відступами тощо. Аналіз текстів сучасних українських письменників дає змогу відслідкувати засоби й прийоми комунікативного зближення автора й читача на грунті дінгвопоетичної парадигми, інтимізації мовлення для посилення іллокуційного впливу на адресата. Виокремлено питання критичного сприймання Яконцепції творця художнього тексту з можливим встановленням зворотного зв'язку у вимірах “авторчитач".

Ключові слова: автор, читач, адресант, адресат, текст, смисл, образ, текстотворення, образотворення, мовомислення, авторська інтенція, інтимізація мовлення. 